\title{
Determination of the Size-topological Parameters the Structure of Cast Iron
}

\author{
K.V. Makarenko ${ }^{1}$, E.A. Zentsova ${ }^{1}$, A.A. Nikitin ${ }^{1}$ \\ makkon1@yandex.ru|kopilka.32@mail.ru|zzzalexzzz95@gmail.com \\ ${ }^{1}$ BSTU, Bryansk, Russian Federation
}

The methods of geometric identification and determination of the main size-topological parameters of the graphite phase in cast iron are studied. The methods used in world practice to identify the form of graphite inclusions are considered. It is proposed to use the methods of fractal geometry for the determination and identification of graphite inclusions in cast iron. A method for determining the size-topological characteristics of the graphite phase in cast iron has been developed. To describe the non-uniformity of the distribution, the lacunarity function was used. An example of determining the size-topological parameters of the graphite phase for various types of cast iron is presented.

Keywords: graphite, inclusion, phase, cast iron, distribution, shape, size, quantity, fractal, lacunarity.

\section{Introduction}

During classification of graphite inclusions according to GOST 3443 - 87, comparative evaluation of real microstructures in relation to the reference images is taken into account. Such method requires from the researcher certain skills and complicates the classification of graphite inclusions during formation of mixed or transitional structures that refer to different classes of cast irons or form in different cross sections of the item.

In national metallography, the analytical methods of determination of graphite inclusions' shapes are developed. There are two main approaches to determine the sizetopological parameters of the structure- with the dimensionless factors of shape or the measuring of inclusions' outline. The simplest of them was suggested by S.A. Saltykov [15] and this approach uses dimensionless factor of shape $(F)$, designed for the evaluation that also includes graphite inclusion, in accordance with the formula(1):

$$
F=3,545 \sqrt{\frac{S}{P}},
$$

where $S$ - the area of inclusion, $\mathrm{P}$ - the perimeter of inclusion

For inclusions of ideal spherical shape $F=1$

O.V. Sotsenko [17] suggested to use apart from the dimensionless factor of shape $\left(F_{K}\right)$, the measuring of the outline to determine the compactness of inclusions:

$$
F_{K}=\frac{S}{S_{o}},
$$

where $S_{o}$ - the area of the circle, made around the inclusion.

On the basis of this method, he developed the reference scales, containing various shape modifications of graphite inclusions, present in cast iron.

The similar reference scale for shape identification in graphite inclusions after the modification and evaluation of their effect on physical-mechanical properties of cast iron was developed by V.I. Litovka [11]. For determination the degree of graphite spheroidization (DGS), he used the formula:

$$
D G S=\frac{\sum_{i=1}^{i=n} F_{i} N_{i}}{\sum_{i=1}^{i=n} N_{i}} 100 \%,
$$

where $F_{i}$ - the magnitude of factor of graphite inclusions, $N_{i}$ - the number of graphite inclusions, included in i-group and having the factor of $F_{i}$ - shape.

For those cases, when in cast iron in the section plane, several different forms of graphite inclusions are observed simultaneously, S.A. Saltykov suggested to use the factor of shape that would take into account the proportions (fractions) of each graphite shape [20],[7]:

$$
F=\sum_{i=1}^{i=n} F_{i} q_{i}
$$

where $F_{i}$ - the factor of graphite inclusions' shape( for graphite of spherical shape, $F=1$, for vermicular shape $F=0,2 \ldots 0,5$, depending on location of its colonies and their sizes); $q_{i}-$ the volume proportion of graphite in each form in the cast iron structure.

Such solution represents the simplified variant, suggested by V.I. Litovka.

I.P. Volchock [18] applied the graphite index which enables to determine simultaneously both the quantity and form of graphite. The index of graphite $\left(\mathrm{Jgr}_{\mathrm{gr}}\right)$ is calculated as a ratio of sum of maximal sizes $a_{i}, i$ - graphite inclusions to length $L$ arbitrary secant, crossing them:

$$
J_{g r}=\frac{\sum a_{i}}{L} .
$$

The similar method was used by S.A. Shevchuck for the evaluation of length of graphite inclusion in grey cast iron [16].

However, in spite of the analytical form of description, these methods are comparative and the classification of graphite inclusions with these methods is performed on the basis of the subjective evaluation of the researcher.

The method of epy metallographic analysis, developed by E. Epanchin [3] deserves special attention. For the determination of inclusions' parameters in alloys, he used the television microscope "Quantimetre" that was modified for the calculation of inclusions' area from the images, received in the raster electronic microscope (REM). The use of the device enabled to identify separate elements of graphite inclusions, not having being registered with other methods [2].

In modern conditions, when different analytical computerized complexes, designed for the metallographic researches, are getting more widespread, the problem of inclusions' identification in the microstructure images is being solved with the help of the specialized software [13], [6].

While developing the software, different methods and algorithms of calculation are used; herewith, the number of the studied parameters, related to the description of inclusions, increases several times. So, the programme Macros III (Carl Zeiss, Vienna, Austria) for the analysis of the evaluation of the sphericity of graphite inclusions in the cast iron with spherical graphite, uses more than 10 different parameters [8].

Brazilian researchers, being engaged in the issues of the identification of graphite inclusions in cast iron, give 5 modifications of the calculation of one factor, applied for the evaluation of the degree of spherical inclusions [14]. Such diversity of parameters and multiplicity of their modifications effects on the deviation of the results in the evaluation of the identical parameters, determined in different analytical systems. 
Besides, often, the software, installed in foreign analytical complexes, does not meet the requirements of GOST 3443-87 and that makes certain difficulties in their usage in the national enterprises.

Meanwhile, there is another approach for solving the problem of the identification of graphite inclusions in cast iron. The approach is based on the researches, proving that the increase of graphite inclusions in cast iron follows the laws of fractal geometry $[1,5,9,10,12,19]$.

\section{The Technique of the Conducting Research}

As a source of the initial images for the analysis, the standard scales of GOST 3443-87 and unetched sections, different in structure and technology of cast iron production, were used.

For the analysis of images of cast irons' microstructure, the programme ImageI was applied. Fractal dimensions were determined with the help of the analytical module FracLac. The module calculates the fractal dimension for binary images by the grid method.

Initially, in the process of operation of the segmentation in the binary image, the programme distinguishes separate inclusions. Then, the computer scanning of each inclusion with the help of the grid with a certain size of the cell is performed. The scanning of the inclusion is performed several times. During each following stage of the scanning, the side of the grid cell increases by one pixel according to the arithmetic progression. In the figure 1, separate stages of the scanning of the longitudinal section of the laminar graphite inclusion, observed in the section plane of grey cast iron, are presented.

The number of stages is determined by the maximal size of the grid cell. Thus, for the inclusion, presented in figure 1 , the number of stages during the scanning by the cells of increasing size was 46. At each stage, the number of cells, containing pixels of the image of $(F)$ inclusion ant their size $(\varepsilon)$, which is calculated as a ratio of the cell square to the total area of the image, is determined. These parameters are used in the calculation of fractal dimensions $\left(D_{\beta}\right)$ according to the formula:

$$
D_{\beta}=\lim _{\varepsilon \rightarrow 0} \frac{\ln F}{\ln \varepsilon} .
$$

The fractal dimension is determined by the slope of the trend line, constructed by the method of the smallest squares in the coordinates $(-\ln \varepsilon)-\operatorname{InF}$ (fig. 2). While using the statistical approach, the fractal dimension is stochastic $\left(D_{\beta}\right)$, and for the evaluation of the accuracy of its results, additionally, the determination coefficient is defined $\left(r^{2}\right)$. For all of the conducted experiments, the determination coefficient has shown a high degree of correlation of the averaged trend line and calculated parameters $r^{2} \in[0,92 ; 0,99]$.
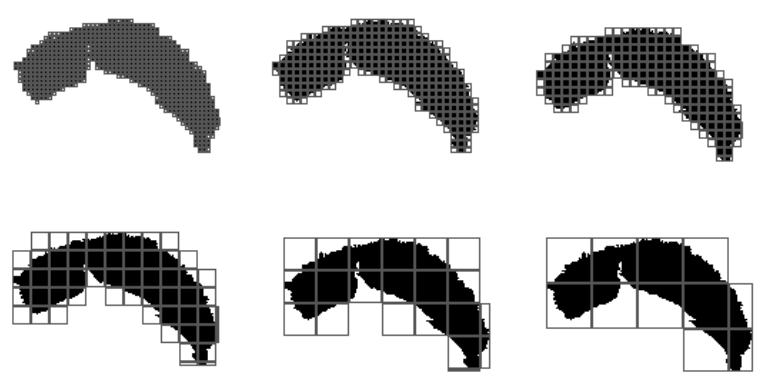

Fig. 1. The results of the separate stages of the scanning of graphite inclusion by the grid method.

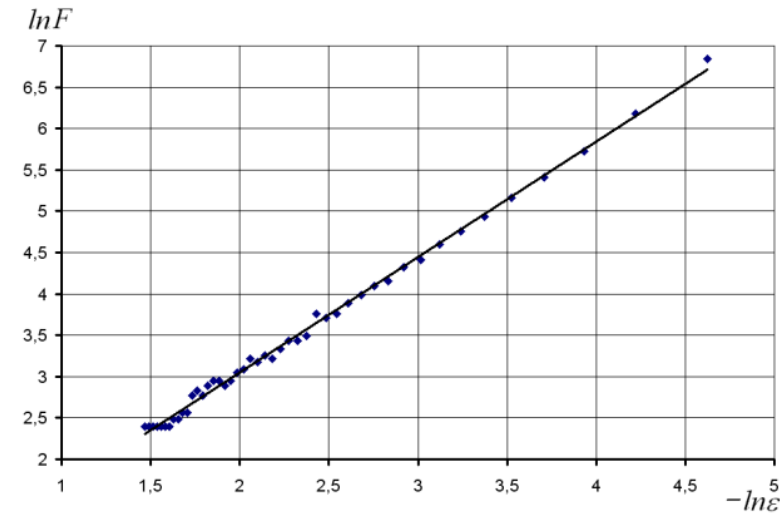

Fig. 2. The graphical method of the determination of the stochastic fractal dimension by the slope of the trend line.

So, the studied structure is presented as a binary array, which is divided into the cells of the given size, and for each cell, the evaluation of the individual elements of the structure is performed, the structure has a correlation with the array of the whole structure.

\section{The Research Results}

A descriptive characteristic in the multifractal formalism is a spectrum of generalized dimensions $D_{q}$. In the spectrum they distinguish a hausdorff $\left(D_{0}\right)$, informational $\left(D_{l}\right)$ and correlational $\left(D_{2}\right)$ dimensions. For more accurate evaluation of the geometrical objects under analysis, the function of the multifractal spectrum $f(\alpha)$ is used.

The microstructure of the pre-eutectic cast iron was studied. The microstructure of cast iron is presented by the dendritic matrix (fig. 3,a) with microfine eutectic interdendritic graphite (fig. $3, b$ ).

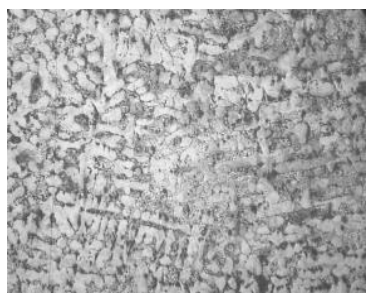

a)

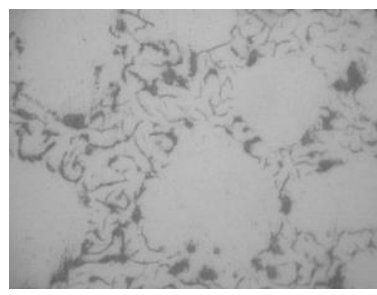

b)
Fig. 3. The Initial cast iron microstructure: $a$-the dendrites of austenite (not etched), $\times 80$; $b$ - interdendretic graphite (not etched), $\times 1000$.

Multifractal parameterization for the evaluation of the geometric parameters of the dendritic structure of the initial austenite and eutectic graphite were performed on the binary images (fig. 4).

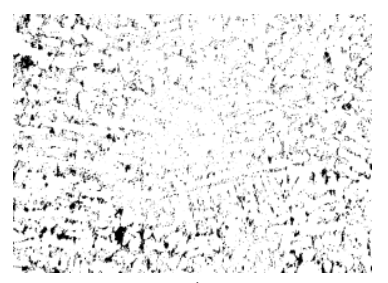

a)

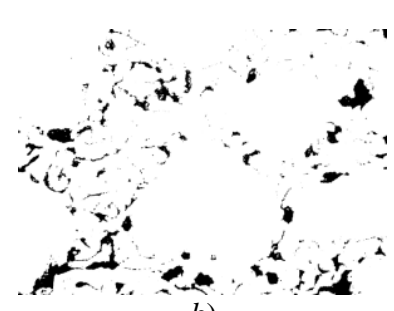

b)
Fig. 4. The binary images of the microstructure, presented in the fig. 3: $a$ - the dendrites of austenite; $b$-interdendretic graphite.

For the multifractal analysis of the images of the cast iron microstructure, the program module FracLac was used that is the plugin of the programme ImageJ. $F(\alpha)$-spectra and spectra 
$D q$ of the generalized Renyi dimensions were analyzied. The results of the analysis are in the fig. 5 .

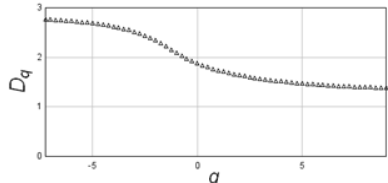

a)

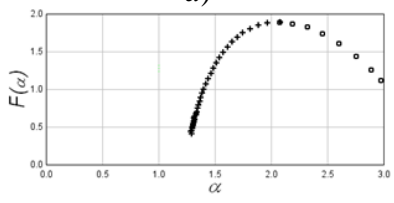

c)

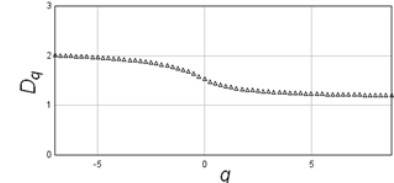

b)

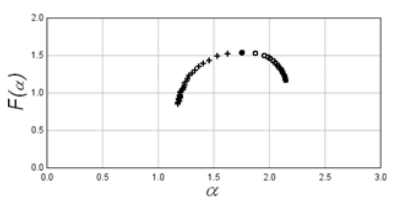

d)
Fig. 5. The spectra of the generalized dimensions: $a$ - for the dendrites of austenite; $b$-for eutectic graphite $f(\alpha)$ - spectra; $c$ - for the dendrites of austenite; $d$ - for eutectic graphite

The presented graphs characterize both microstructures as multifractal ones $D_{q}>D_{q}^{\prime}$ at $q^{\prime}>q$. The analysis of the Hausdorff dimension $D_{0}$ (dendr.austen) $=1,89>D_{0}$ (eutect.graph) $=1,54$ shows that the dendritic structure of the austenite, having predominant fractal dimension, is the leading one in the structure formation of cast iron. The graphite phase stands out in the interdendrertic intervals and in fact, fits within the certain limits, dictated by the initial $\gamma$-phase, herewith the fractal dimension of the graphite phase as a geometric object will be lower than the one of the dendrites of austenite.

The method of the determination of the fractal dimension can be used for the analysis of the processes of the structure formation and for the evaluation of the processes of the phases' evolution in new alloys. Except the general study of the images of the material microstructures, the fractal analysis can be used for the determination of the morphological parameters of the graphite phase, as these parameters can't be determined numerically by standard methods. Distribution and shape of graphite inclusions belong to such parameters.

\section{The Discussion of Results}

Before the study of the microstructure of different cast irons, the calibration measurements of the standard scales of the images, presented in appendix 3 to GOST 3443-87, were conducted. Such analysis enabled to match the fractal dimensions with the standardized shape of graphite inclusions. At first, the scale of the fractal dimensions of the inclusions, observed in the section plane, was accepted from $D_{\beta}=1$, what corresponds to the segment, to $D_{\beta}=2$-the ideal circle in the plane. During the study of the standard scales of the images of GOST 3443-87, the inclusions with the ideal circular shape were not found, that's why the upper value of the interval was decreased to $D_{\beta}=1,9$. The range of the fractal dimensions covers all of the observed ones, that have been during the study of graphite inclusions in cast irons (of GOST 3443-87).

The range of the fractal dimensions was divided according to the scales of GOST 3443-87 into five stages of the graphite "compactness". The first stage $[1,0 \ldots 1,09]$ correspond to the laminar acicular shape of graphite (PGf3); the second one $[1,1 \ldots 1,29]$ to the laminar rectilinear (PGf1); the third stage $[1,3 \ldots 1,49]$ - to the laminar swirling (PGf2) and nesting (PGf4), and also to the vermicular twisting (VGf2); the fourth stage $[1,5 \ldots 1,69]$ - to the vermicular nodular (VGf1) and thickened (VGf3), and to the structure of malleable cast iron- filamentary (KGf1) and flocculent (KGf2); the last fifth stage [1,7 ..1,9] includes the compact shape of malleable cast iron inclusions
(KGf3) and the whole scale, belonging to the cast iron with the spherical graphite (ShGf1...ShGf5). To simplify the identification of graphite inclusions, the color scale was used, on which the separate stages of the fractal dimensions of the inclusions' shape had their own colors.

The examples of the use of fractal analysis for the identification of graphite inclusions in cast irons of different brands, are represented in the fig. 6 .

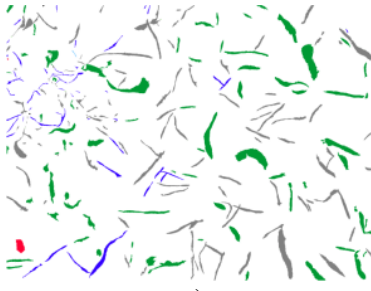

a)

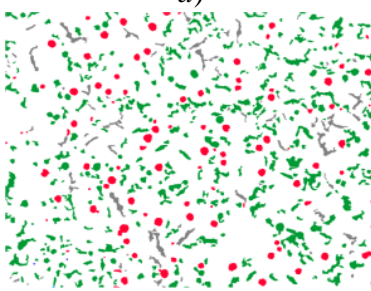

c)

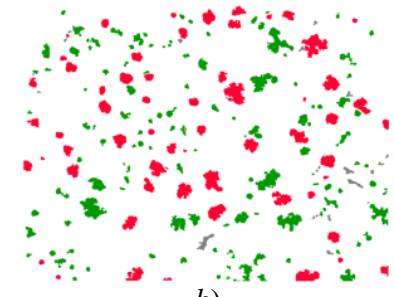

b)

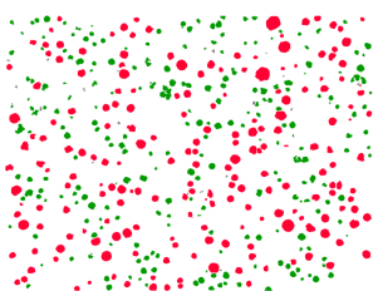

d)
Fig. 6. The examples of the identification of graphite

inclusions in the samples, $\times 100: a$-grey cast iron;

$b$ - malleable cast iron; $c$ - cast iron with the vermicular graphite; $d$-ductile cast iron.

In the fig.6, $b$ - the image of the microstructure of the ferrite malleable cast iron is presented. In the structure, the compact inclusions that belong according to the fractal dimensions, to the fourth and fifth stages, predominate.

The structure of the sample from the cast iron with the vermicular graphite (fig.6, c) contains the inclusions of three stages of compactness, except the first two ones. The compact inclusions of the circular shape are identified in the local parts of cast iron. The vermicular twisting shape of graphite inclusions (VGf2) belongs to the third stage of the scale. In the structure, the compact shape of graphite inclusions, belonging to the fourth stage of the compactness scale, predominates.

The microstructure of the ductile cast iron, used for the fractal analysis, is shown in the fig. $6, d$. The small inclusions of incorrect configuration, observed in the structure, have a compact shape, belonging to the fourth stage of the scale. Large inclusions of graphite are identified as spherical ones.

Except the shape of graphite inclusions, during the computer analysis, the parameters, characterizing quantity, size and distribution of the graphite phase in cast irons, can be numerically identified.

The quantity of the graphite phase $\left(S_{g r}\right)$ in cast iron is calculated from the ratio of the number of black pixels $\left(C_{g r}\right)$, characterizing the content of the graphite phase, observed in the plane of the not etched section, to the total number of pixels of the image $\left(C_{i m}\right)$ :

$$
S_{g r}=\frac{C_{g r}}{C_{i m}} 100 \% .
$$

The size of graphite inclusions $\left(A_{g r}\right)$ is evaluated according to the sum of the square of graphite inclusions $\left(S_{i}\right)$ to the total number of inclusions $(n)$, segmented on the image of the microstructure:

$$
A_{g r}=\frac{\sum_{i=1}^{i=n} S_{i}}{n} .
$$


The formula enables to determine the index, characterizing the average square of graphite inclusions in pixels.

For the evaluation of distribution of graphite inclusions, it is necessary to use not only the local analysis of separate inclusions but also the general fractal analysis of the whole image. Herein, the lacunarity is used that characterizes the nonuniformity of the image fill by pixels, belonging to the graphite phase.

The calculation results of the parameters of the graphite phase in cast irons of different brands are shown in the table.

\begin{tabular}{|c|c|c|c|c|}
\hline \multirow{2}{*}{ Cast iron } & \multicolumn{3}{|c|}{ The evaluated parameter of graphite inclusions } \\
\cline { 2 - 5 } & $\begin{array}{c}\text { Shape } \\
\text { The } \\
\text { average } \\
\text { fractal } \\
\text { dimension } \\
\text { of } \\
\text { inclusions, } \\
D_{\beta}\end{array}$ & $\begin{array}{c}\text { The } \\
\text { average } \\
\text { area of } \\
\text { inclusions, } \\
A_{g r} \text {, nKc. }\end{array}$ & $\begin{array}{c}\text { Quantity } \\
\text { of content } \\
\text { graphite } \\
\text { phase on the } \\
\text { image, } \\
S_{g r}, \%\end{array}$ & $\begin{array}{c}\text { Distribution } \\
\text { The lacunarity } \\
\text { of theimage, } \\
\Lambda\end{array}$ \\
\hline $\begin{array}{c}\text { Grey } \\
\text { (fig. 6, } a \text { ) }\end{array}$ & 1,42 & 815 & 8,5 & 1,38 \\
\hline $\begin{array}{c}\text { Malleable } \\
\text { fig. 6, } b \text { ) }\end{array}$ & 1,63 & 993 & 10,6 & 1,44 \\
\hline $\begin{array}{c}\text { With the } \\
\text { vermicular } \\
\text { graphite } \\
\text { (fig. 6, } c \text { ) }\end{array}$ & 1,59 & 547 & 15,3 & 1,6 \\
\hline $\begin{array}{c}\text { Ductile } \\
\text { (fig. 6, } d \text { ) }\end{array}$ & 1,72 & 504 & 11,8 & 1,46 \\
\hline
\end{tabular}

All the parameters, presented in the table 3 , have not descriptive but particular numerical values; they can be used for the development of the mathematical models of correlation of mechanical properties with the structure of cast irons.

\section{Conclusion}

With the use of the method of the fractal analysis of images, the problem of the determination of the size-topological parameters of the graphite phase is solved. The shape of graphite inclusions is determined with the correspondent fractal dimension and the distribution- with the lacunarity that characterizes the non- uniformity of the fill of some object in space. The method of the determination of the size and quantity of the graphite phase in the section plane by the methods of the computer processing of the cast irons' microstructure images is developed.

\section{References}

[1] Anvarov A.D., MaminovA.S.,Bulkin V.A., Vstovskiy G.V. (2006) Perspektiva ispol'zovaniya metoda miltifrktal'nogo analiza izobrazheniy struktury metalla $\mathrm{v}$ reshenii zadach obespecheniyabezopasnoy ekspluatutsii tekhnicheskikh ustroystv opasnykh proizvodstvennykh ob"ektov [The perspective of the using the method of themultifractal analysis of the metal structure images to provide the safe operation of technical equipment, belonging to the hazardous production faclilities]. Kontrol'. Diagnostika, no 7, pp.17-22.

[2] Epanchintsev O.G. (1970) Raspredeleniye grafitnykh vklyucheniy po razmeram $\mathrm{v}$ serom chugune [The distribution of graphite inclusions according to the size in grey cast iron]. Liteynoye proizvodstvo, no 12, pp. 21-22.

[3] Epanchintsev O.G. (1970) Avtomaticheskiy metod metallograficheskogo analiza vklyucheniy [The automatic method of the metallographoc analysis of inclusions]. Liteynoye proizvodstvo, pp.27-29.

[4] Epanchitsev O.G., Zaytsev V.V.,Shebatinov M.P., Shnyryov G.D. (1970) Avtomaticheskiy metod metallograficheskogo analiza vklyucheniy [The automatic method of the metallographoc analysis of inclusions]. Liteynoye proizvodstvo, no 9, pp. 29-31.

[5] Falconer K. (1997) Techniques in Fractal Geometry. John Wiley \& Sons, p. 256 (in Russ.).

[6] Filinov M.V. (2005) Problemy komp'yuternoy klassifikatsii struktur $\mathrm{v}$ nerazrushayu shchem kontrole [The problems of the computer classification in nondestructive testing]. Kontrol. Diagnostika, no 4, pp. 1519.

[7] Il'icheva L.V., Andreev V.V., Bulatnikova V.I., Barmykov A.S. (1984) Vliyaniye parametrov grafita i strukturnykh sostavlyayushchkh matritsy na mekhanicheskiye svoystva chuguna [The influence of the graphite parameters and the structural components of matrix on the mechanical properties of the ductile cast iron]. Liteynoye proizvodstvo, no 7, pp. 2-4.

[8] Imasogie B. I. (2004) Characterization of Graphite Particle Shape in Spheroidal Graphite Iron Using a ComputerBased Image Analyzer. Journal of Minerals \& Materials Characterization \& Engineering, vol. 3, no 1. - pp. 1-12.

[9] Li J. (2000) Quantitative Analysis of the Irregularity of Graphite Nodules in Cast Iron. Materials Characterization, vol. 45 , pp. 83-88.

[10] Li J. (2000) Fractal growth of graphite nodules in iron. Philosophical Magazine Letters, vol. 80, no 9, pp. 633640.

[11] Litovka V.I. (1987) Povysheniye kachestva vysokoprochnogo chuguna v otlivkakh [The improvement of the ductile cast iron' quality in the castings]. Kiev: Naukova dumka, p. 206 (in Russ.).

[12] Mandelbrot B. (2002) Fraktal'naya geometriya prirody [The fractal geometry of nature]. Moscow: The Institute of Computer Studies, p.656.( in Russ.).

[13] Mel'nikov A.P. (2002) Primeneniye komp'yuternykh tekhnologiy v metallograficheskom analize [The use of the computer technologies in the metallographic analysis]. Liteynoye proizvodstvo, no 1, pp. 31-32.

[14] Otávio da Fonseca M.G. (2005) Automatic Classification of Graphite in Cast Iron. Microscopy and Microanalysis., vol. 4, no 11, pp. 363-371.

[15] Saltykov S.A. (1970) Stereometricheskaya metallografiya [Stereometrical metallography]. Moscow: Metallurgiya, $\mathrm{p}$. 376 (in Russ.).

[16] Shevchuck S.A. (1971) Otsenka dliny vklyucheniy grafita $\mathrm{v}$ chugune [The evaluation of the inclusions' length in cast iron]. Liteynoye proizvodstno, no 7, pp. 32-33.

[17] Sotsenko O.V. (1982) Otsenka kompaktonosty fkluycheniy grafita v vysokoprochnom chugune [The evaluation of the graphite compactness in the ductile cast iron]. Liteynoye proizvodstvo. no 6, pp. 5-8.

[18] Volchock I.P. (1993) Soprotivleniye razrusheniyu stali i chuguna [The fracture resistance of steel and cast iron]. Moscow: Metallurgiya, pp. 192 (in Russ.).

[19] Vstovskiy G.V. (2001) Vvedeniye v mul'tifraktal'nuyu parametrizatsiyu struktur materialov [The introduction to the multifractal parametrization of the materials' structures]. Vstovskiy G.V., kolmakov A.G., Bunin I.Zh. Moscow-Izhevsk:Nauch.-izd. Tsentr “ Regulyarnaya i Khaoticheskaya dinamika”, p.116.(in Russ.).

[20] Yakovlev F.I. (1986) Vliyaniye formy grafita i dispersnosty martensita na mekhanicheskiye svoystva vysokoprochnogo chuguna [The influence of the graphite shape and the martensite dispersion on the mechanical properties of the ductile cast iron]. Metallovedeniye $i$ termicheskaya obrabotka materialov [Metallurgy and the heat treatment of materials],. no 5, pp.55-56. 